\title{
Open Reduction of Supracondylar Humerus Fractures in Children for Failed Closed Reduction: Outcome of Delayed Treatment
}

\author{
Yoyos Dias Ismiarto, Mahyudin, Adriel Benedict Haryono \\ Department of Orthopaedics and Traumatology Faculty of Medicine Universitas Padjadjaran \\ Dr. Hasan Sadikin General Hospital Bandung, Indonesia
}

\begin{abstract}
Supracondylar fractures of the humerus are common in children and the advocated treatments for these fractures include closed reduction and percutaneous pinning. There are numerous debates on the intervention period selection for delayed treatment in children. This phenomenon is prevalent in regions with limited healthcare support. The objective of this study was to compare the outcome of early and late treatment groups, including preliminary presentations and the management of failed treatment. This was a prospective comparative study on early and late open reduction, featuring Kirschner wire fixation for Gartland type III supracondylar fracture of humerus in children aged less than 18 years. Patients from January 2018 to January 2019 were categorized into early and late groups $(n=22$ and $n=26)$, consisting of $33(86.8 \%)$ males and $15(31.2 \%)$ females. Flynn's criteria were used to evaluate them. The average time from injury to surgery was $50.24 \pm 23.5$ hours in the early group and $373.79 \pm 89.23$ hours in the late group $(\mathrm{p}<0.002)$. While the Bauman's angle recorded after 12 weeks presented the values of $82.04 \pm 5.18$ and $77.38 \pm 6.43(\mathrm{p}=0.622)$ for the early and late groups, respectively. Pre-operative nerve injuries were observed only in $4(8.33 \%)$ cases from the early group. The functional outcomes of both categories were not significantly different statistically $(\mathrm{p}=0.242)$. The outcome for children with supracondylar humerus fracture Gartland type III was satisfactory in both groups. In conclusion, treatment delay does not result in a difference in the outcome according to Flynn's criteria.
\end{abstract}

Keywords: Children, delayed, early, fracture, supracondylar

\section{Reduksi Terbuka Fraktur Suprakondiler Humerus pada Anak dengan Gagal Reduksi Tertutup: Hasil Pengobatan Tertunda}

\begin{abstract}
Abstrak
Fraktur suprakondiler humerus umum terjadi pada anak-anak dan tatalaksana yang dianjurkan termasuk reduksi tertutup dan percutaneous pinning. Tujuan dari penelitian ini adalah membandingkan hasil dari kelompok dengan tatalaksana dini dan tertunda, termasuk gambaran klinis awal dan manajemen untuk tatalaksana yang gagal. Penelitian ini melibatkan studi prospektif dan perbandingan reduksi terbuka dini dan akhir dengan fiksasi kawat Kirschner untuk fraktur suprakondiler Gartland tipe III pada anak-anak berusia kurang dari 18 tahun. Pasien dari Januari 2018 hingga Januari 2019 dikategorikan ke dalam kelompok dini dan akhir ( $\mathrm{n}=22$ dan $\mathrm{n}=26$ ), terdiri atas $33(86,8 \%)$ laki-laki dan $15(31,2 \%)$ perempuan. Data diambil dari rekam medis pasien di Rumah Sakit Dr. Hasan Sadikin Bandung. Kriteria Flynn digunakan untuk mengevaluasi. Rata-rata waktu cedera hingga operasi adalah 49,72 $\pm 32,1$ jam pada kelompok dini 421,25 $\pm 82,16$ jam dan pada kelompok akhir $(\mathrm{p}<0,002)$. Sedangkan

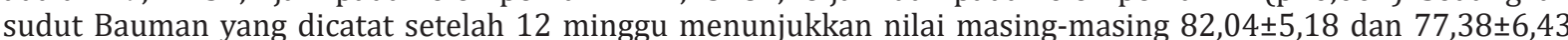
$(\mathrm{p}=0,622)$ untuk kelompok dini dan akhir. Cedera saraf praoperasi diamati hanya pada $4(8,3 \%)$ kasus dari kelompok dini. Hasil fungsional dari kedua kategori tidak berbeda secara statistik $(\mathrm{p}=0,242)$. Hasil pengobatan untuk anak-anak dengan fraktur suprakondiler humerus Gartland tipe III memuaskan pada kedua kelompok. Simpulan, keterlambatan pengobatan tidak menyebabkan perbedaan hasil sesuai dengan kriteria Flynn.
\end{abstract}

Kata kunci: Anak, dini, fraktur, suprakondiler, tertunda

Corresponding Author: Yoyos Dias Ismiarto, Department of Orthopaedics and Traumatology Faculty of Medicine Universitas Padjadjaran/Dr. Hasan Sadikin General Hospital Bandung, Jalan Pasteur No. 38 Bandung, West Java, Indonesia, Email: yoyosismiartounpad@gmail.com 


\section{Introduction}

Supracondylar fractures of the elbow accounts for $16.6 \%$ of all fractures in pediatric patients. ${ }^{1,2}$ A broad range of non-operative and operative methods have been developed to restore normal elbow anatomy, including long-arm plaster cast immobilization; axial traction application with tape or a trans-olecranon pin; elastic and stable intramedullary nailing; and external fixation..$^{2-4}$ In addition, percutaneous pinning is widely adopted as the most advanced technique. Open surgery is often indicated in patients with unstable and compound fractures, as well as those with vascular complications..$^{1-3}$ In the case of unstable supracondylar fractures of the humerus among children, the standard treatment involves closed reduction, followed by stabilization with percutaneous Kirschner wires. Moreover, numerous studies have demonstrated satisfactory outcomes. ${ }^{2-4}$

It is widely known that Gartland type I and type II fractures have been accurately treated using the conservative treatment. In contrast, the modalities for type III include sidearm traction; overhead skeletal traction; closed reduction and casting with or without percutaneous pinning; and also open reduction and internal fixation. ${ }^{3-4}$ It is albeit highly challenging to manage displaced fractures with closed reduction and pop cast due to the loss of reduction and missing coronal tilt on a radiograph, thus causing cubitus varus deformity. 5,6

Delays in seeking treatment are commonly seen in developing countries. ${ }^{9,10}$ Hence, this retrospective study had the purpose to compare the results from early and late presentation and management cases.

\section{Methods}

This study used secondary data obtained from the outpatient and inpatient medical records of orthopedic patients with supracondylar humerus fractures visiting or admitted to the Pediatric Surgery Department of Dr. Hasan Sadikin general Hospital Bandung, Indonesia, from January 2018 to January 2019. Surgery was conducted on a total of 48 children with supracondylar elbow fractures. Patients were designated into Group A, children undergoing operative treatment within 7 days of injury, and Group B, children receiving operative treatment after 7 days of injury and within 30 days. Results from 22 and 26 cases for Group A and B, respectively, that represented early and late groups were evaluated in the final analysis. The inclusion criteria used in this study were patients that declined treatment with closed reduction; categorized into category of Gartland type III Supracondylar Humerus Fracture; children below 18 years of age; and, for the late group or group B, delayed treatment more than 7 days.

Patients were treated with open reduction and k-wire fixation by medial approach and minimum incision to enable the visualization of ulnar nerve at the medial side using two crossed $\mathrm{k}$ wires. Subsequently, immediate postoperative complications were recorded, and the wound was monitored for 2 days post-surgery. In the absence of any complications, patients were discharged after 48 hours, and an above elbow posterior slab was used postoperatively for 3 weeks.

The patients were further reviewed after 2 weeks (pin tract infection, suture removal) and 12 weeks. The process involved the evaluation of pain, motion range, evidence of union, infection, or for any external malrotation, dorsal and volar angulation and myositic mass. Therefore, fresh radiographs were captured during every visit, and the final follow up evaluationwas based on the flexion-extension arc of both the injured \& uninjured elbow. In addition Bauman`s angle was used for the radiographic assessment of both elbows, while Flynn`s criteria was used to assess the patient in the last visit (12 weeks).

Data is collected and analyzed using SPSS using chi-square and presented in tables and graphs. This study approved by Health Research Ethics Committee Dr. Hasan Sadikin General Bandung with ethical clearance number LB.02.01/X.6.5/160/2021.

\section{Results}

There were no significant differences between the early and late groups in this study in terms of age, intraoperative time, postoperative changes in Baumann's angle, hospital stays, and loss of motion range at 12 weeks. All patients presented with fall injury, encompassing thirty-three (86.8\%) males and 15 (31.2\%) females. This data were highly similar to other studies, where $22(45.8 \%)$ patients in the early group were admitted within 24 hours of injury, while 26 (54.1\%) presented between day 1 to 6 . Moreover, 2 patients in this current study demonstrated complications in the form of mild fever, swelling, and serous discharge, which was totally absent 
YD Ismiarto et al: Open Reduction of Supracondylar Humerus Fractures in Children for Failed Closed Reduction: Outcome of Delayed Treatment

Table 1 Comparison of Patient Profiles between Early and Late Surgery Groups

\begin{tabular}{lccc}
\hline \multirow{2}{*}{ Variables } & \multicolumn{2}{c}{ Group (Mean \pm SD) } & \multirow{2}{*}{ P value } \\
\cline { 2 - 3 } & Early & Late & 0.346 \\
\hline Age (years) & $9.33 \pm 1.67$ & $8.76 \pm 2.66$ & 0.000 \\
Injury to surgery time (hours) & $50.24 \pm 23.5$ & $373.79 \pm 89.23$ & 0.372 \\
Hospital stays (days) & $5.3 \pm 4.55$ & $4.8 \pm 5.32$ & 0.412 \\
Baumann's angle (degree) 12 weeks & $78.54 \pm 4.37$ & $75.43 \pm 2.34$ & \\
\hline
\end{tabular}

Table 2 Comparison Between Arc of Motion

\begin{tabular}{cccc}
\hline Variables & Early (mean \pm SD) & Late (mean \pm SD) & P value \\
\hline Arc of motion 12 weeks & $128.62 \pm 8.43$ & $119.93 \pm 16.31$ & 0.521 \\
\hline
\end{tabular}

in the late groups. Furthermore, no participants experienced surgical site infection at the end of 12 weeks follow up period in either group, which was marked by the absence of pain.

Table 3 shows the excellent results in 17 $(77.2 \%)$ patients from the early group, while 19 (73.1\%) in the late group demonstrated the best outcome. In addition, 3 (13.6\%) and 4 (15.3\%) patients, respectively, had good results, while poor results were observed in $2(10 \%)$ and 3 (11.5\%) patients. Moreover, no participant in either category had a fair result, at $p$-value of 0.242 , which is not significant, being $>0.05$.

\section{Discussion}

A fall often causes major injuries and playing with a bicycle was identified as the highest instigator in the early group (38.23\%). Meanwhile, playing caused the maximum injury (45.2\%) in the late group, which is consistent with other studies. ${ }^{10-13}$ The treatment option besides closed reduction is opening reduction with pinning. Open reduction is indicated in the cases of failed closed reduction, loss of pulse or poorly perfused hand following reduction and in the case of open fracture. ${ }^{13}$

Crossed medial and lateral pinning via lateral approach are performed with minimal incision on the medial side to visualize ulnar nerve. Despite the cut made during the procedure, no postoperative ulnar nerve injury was reported, and there was also no case of reduction loss during attempts to engage the opposite cortex. However, recent literature show that the use of only lateral pinning is sufficient for fixing supracondylar fracture..$^{11-15}$

Bayisenga J. et al evaluated early outcomes of open reduction and internal fixation of Lagrange and Rigault stage IV supracondylar humerus fractures in children in Rwanda using K-wires pinning. Their result confirmed the effectiveness of this method, especially in cases of delayed treatment and in settings with no intensifier imaging. In addition, there was no increase in the complication rate. ${ }^{20}$

The results of the presence study showed a nonexistence of non-union cases in both groups, as the distal humerus is an unusual location. ${ }^{16,17}$ Therefore, all patients experienced clinical and radiological union within 3 weeks, as well as united fractures at the 12-week followup. These findings are congruent with studies conducted by others; hence, open reduction and internal fixation procedure is confirmed not to be a concern for bony union. Furthermore, the assessment using Flynn's criteria showed no significant difference between the outcomes of

Table 3 Comparison of Flynn's Functional Criteria in Early and Late Groups

\begin{tabular}{lccc}
\hline \multirow{2}{*}{ Flynn's Criteria } & \multicolumn{2}{c}{ Group } & p-value \\
\cline { 2 - 3 } & Early (n=22) (\%) & Late (n=26) (\%) & \\
\hline Excellent & $17(77.2)$ & $19(73.1)$ & 0.242 \\
Good & $3(13.6)$ & $4(15.3)$ & \\
Fair & & & \\
Poor & $2(10)$ & $3(11.5)$ & \\
\hline
\end{tabular}


both treatment groups $(\mathrm{p}=0.242) .{ }^{15-18}$

In the early group of this study, the Flynn's criteria presented excellent results in $77.2 \%$ and good results in $13.6 \%$ cases; however, $10 \%$ exhibited poor outcome. In the late group, the corresponding results $\mathrm{f}$ were $73.1 \%, 15.3 \%$ and $11.5 \%$. Data obtained for arc of motion, range of motion, loss of flexion, extension, and change in Baumann's angle were comparable between both groups, with a p-value of $>0.05$. This outcome possibly resulted from soft tissue injuries, posttraumatic remodeling, fibrous surgical scars, and malunion. . $^{15,16}$

In a previous observational study performed on 31 children with supracondylar humerus fractures, Herring et al. $^{20}$ reported the presentation of severe swelling or skin problems around the elbow in delayed treatments, and also unique health facility problems. Hence, surgical treatments, including the sentiment manual reduction through a medial approach and percutaneous cross-pinning, were provided. Based on these results, delayed presentation is confirmed as not to increase complication rates or unsatisfactory results.

Although there is a growing agreement that pin fixation provides best results, there is some controversy regarding the timing of treatment. Some fractures, such as type III fractures, are considered as an orthopaedic emergency that had to be treated immediately. However, recent studies showed good results even if it is not treated urgently. ${ }^{20}$

This study is imited by the small sample size and constrained follow-up duration, resulting from poor patient cooperation. Based on the result, displaced Gartland type III supracondylar humerus fractures in children can be effectively treated with anatomical reduction and stable fixation. In addition, the treatment outcome was adequate in both groups, and late complications are also avoided.

\section{References}

1. Vaquero-Picado A, González-Morán G, Moraleda L. Management of supracondylar fractures of the humerus in children. EFORT open reviews. 2018;3(10):526-40.

2. Kumar V, Singh A. Fracture supracondylar humerus: A review. Journal of clinical and diagnostic research: JCDR. 2016;10(12): RE01.

3. Clair JB, Schreiber VM. Supracondylar humerus fractures. Operative Techniques in
Orthopaedics. 2019;29(1):11-6.

4. Patriota GS, Assunção Filho CA, Assunção CA. What is the best fixation technique for the treatment of supracondylar humerus fractures in children?. Revista brasileira de Ortopedia. 2017;52(4):428-34.

5. Pham TT, Accadbled F, Abid A, Ibnoulkhatib A, Bayle-Iniguez X, Wargny M, et al. Gartland types IIB and III supracondylar fractures of the humerus in children: is Blount's method effective and safe?.J Shoulder Elbow Surg. 2017;26(12):2226-31.

6. Tomori Y, Nanno M, Takai S. Clinical results of closed versus mini-open reduction with percutaneous pinning for supracondylar fractures of the humerus in children: $A$ retrospective case-control study. Medicine (Baltimore). 2018;97(45):e13162.

7. Gattu A, Babu K. Percutaneous pinning in displaced supracondylar fracture of humerus in children. IJOS. 2017;3(3):156-60.

8. Surapaneni SB, Koneru S, Tummala VS, Boyapati G, Vithala S. Management of displaced supracondylar fracture of humerus in children by closed reduction and $\mathrm{K}$ wire fixation. Int J Orthop Sci. 2017;3:495-8.

9. Prashant K, Lakhotia D, Bhattacharyya TD, Mahanta AK, Ravoof A. A comparative study of two percutaneous pinning techniques (lateral vs medial-lateral) for Gartland type III pediatric supracondylar fracture of the humerus. J Orthop Traumatol. 2016;17(3):223-9.

10. Prakashappa TH, Manik Rana D, Avinash P. Functional outcome in surgical management of supracondylar fracture of humerus in children. Int J Orthopaedics. 2020;6(1):1078-81.

11. Afaque SF, Singh A, Maharjan R, Ranjan R, Panda AK, Mishra A. Comparison of clinicradiological outcome of cross pinning versus lateral pinning for displaced supracondylar fracture of humerusinchildren:Arandomized controlled trial. J Clin Orthopaedics Trauma. 2020;11(2):259-63.

12. al-Algawy AA, Aliakbar AH, Witwit IH. Open versus closed reduction and K-wire fixation for displaced supracondylar fracture of the humerus in children. Eur J Orthop Surg Traumatol. 2019;29(2):397-403.

13. Skaggs DL, Flynn JM. Supracondylar fractures of the distal humerus. Flynn JM, Skaggs DL, Waters PM (eds). Rockwood and Wilkins' Fractures in Children. 8th ed. Philadelphia: Wolters Kluwer; 2015.

14. Matuszewski Ł, Okoński M. Retrospective 
YD Ismiarto et al: Open Reduction of Supracondylar Humerus Fractures in Children for Failed Closed Reduction: Outcome of Delayed Treatment

epidemiological study of supracondylar fractures of the humeral bone in children from urban and rural areas of the Lublin region in eastern Poland. Ann Agric Environ Med. 2013;20(2):401-4.

15. Waikhom S, Mukherjee S, Ibomcha I, Digendra A, Sohkhlet HR. Delayed open reduction and k-wire fixation of widely displaced supracondylar fractures of humerus in children using medial approach. J Clin Diagn Res. 2016;10(8):RC06-10.

16. Shenoy PM, Islam A, Puri R. Current management of paediatric supracondylar fractures of the humerus. Cureus. 2020; 12(5):e8137

17. Lewine E, Kim JM, Miller PE, Waters PM, Mahan ST, Snyder B, et al. Closed versus open supracondylar fractures of the humerus in children: a comparison of clinical and radiographic presentation and results. J Pediatr Orthop. 2018;38(2):77-81.

18. Hussain S, Ahmad M, Muzaffar T. Open reduction and internal fixation for displaced supracondylar fractures of the humerus in children with crossed K-wires via lateral approach. Hin J Traumatol. 2014;17(3):1305.

19. Sahoo BS, Chand DK. Results of treatment of displaced supracondylar fractures of humerus in children by closed reduction and percutaneous pinning. Int J Orthopaedics. 2019;5(4):8-12.

20. Herring JA, Ho C. Supracondylar fractures of the humerus. Herring JA (ed). Tachdjian's Pediatric Orthopaedics Vol 3. 5th ed. Philadelphia: Elsevier Saunders; 2015. 